\title{
The Profitability of Fertilizer Micro Dosing and Timing of Weeding in Finger Millet Production in the Semi-Arid Areas of Uganda
}

\author{
Joseph Ekwangu ${ }^{1, ~ *}$, John Steven Tenywa ${ }^{2}$, Jenipher Bisikwa ${ }^{2}$, Charles Andiku ${ }^{1,3}$, Helen Opie ${ }^{1}$, \\ Paul Anguria ${ }^{1}$, Monday Moses Paga ${ }^{2}$, Deborah Lillian Nambirye ${ }^{2}$, Michael Adrogu Ugen ${ }^{1}$, \\ Nelson Wanyera ${ }^{1}$ \\ ${ }^{1}$ National Semi-Arid Resources Research Institute (NaSARRI), Soroti, Uganda \\ ${ }^{2}$ Department of Agricultural Production, College of Agricultural Sciences, Makerere University, Kampala, Uganda \\ ${ }^{3}$ Department of Crop Production and Management, Faculty of Agriculture and Animal Sciences, Busitema University, Tororo, Uganda
}

Email address:

jekwangu@gmail.com (J. Ekwangu)

${ }^{*}$ Corresponding author

\section{To cite this article:}

Joseph Ekwangu, John Steven Tenywa, Jenipher Bisikwa, Charles Andiku, Helen Opie, Paul Anguria, Monday Moses Paga, Deborah Lillian Nambirye, Michael Adrogu Ugen, Nelson Wanyera. The Profitability of Fertilizer Micro Dosing and Timing of Weeding in Finger Millet Production in the Semi-arid Areas of Uganda. International Journal of Agricultural Economics. Vol. 6, No. 3, 2021, pp. 139-144. doi: $10.11648 /$ j.ijae.20210603.16

Received: April 27, 2021; Accepted: May 14, 2021; Published: June 29, 2021

\begin{abstract}
Despite the recommendation for fertilizer use in crop production by research, there is a low rate of adoption among farmers. The low adoption rate of fertilizer usage has been partly attributed to high costs of fertilizer in addition to use of agronomic recommendation without fertilizer economic analysis. The study therefore, set out to determine the profitability of fertilizer micro dosing and weeding regimes in finger millet production in eastern Uganda. A randomized complete block design in split plot treatment arrangement with three replications was used. Weeding regime treatments were the main plot and fertilizer micro dosing treatments as the sub plots. The treatments included: different micro dosing rates of nitrogen and phosphorus, weeding regimes and SEREMI II finger millet variety. Nitrogen was applied in the form of urea (46\%), in two splits of $50 \%$ each at vegetative and flowering stages respectively. The results of the study indicate that weeding once at 20 Days After Sowing (DAS) and a combination of N and P $\left(16.6 \mathrm{~kg} \mathrm{~N}^{-1}\right.$ and $\left.10.6 \mathrm{~kg} \mathrm{P} \mathrm{h}^{-1}\right)$ fertilizer micro dose application is the most profitable combination and could make farmers earn up to Uganda shillings 1,984.220 per hectare compared to only Uganda shillings 373,000 from none application of fertilizer. We therefore conclude that finger millet producers can achieve higher economic and environmental gains when weeding is done once at 20 DAS in combination with sole P fertilizer micro dosing applied at $10.6 \mathrm{~kg} \mathrm{P} \mathrm{ha}^{-1}$.
\end{abstract}

Keywords: Fertilizer Micro Dosing, Time of Weeding, Profitability, Finger Millet, Uganda, Gross Margin

\section{Introduction}

Finger millet (Eleusine coracana L.) like all other cereals in Africa is mostly grown by smallholder farmers under rain fed conditions with low input use. Past studies have shown high labor requirements especially for weeding and declining soil fertility, diseases and low yield cultivars as major constraints to finger millet production [7, 18, 20]. Low soil fertility has been reported as a major production constraint to crop production in sub Saharan Africa resulting in low crop yields [6] which is further aggravated by limited use of organic soil amendments and high cost of inorganic fertilizers [23]. Therefore, fertilizer micro-dosing (FMD) has been promoted in sub-Saharan Africa (SSA) to boost crop productivity on smallholder farms where production is predominantly done with low use of inorganic fertilizers. The practice involves application of small amounts of mineral fertilizer ( 2 to $6 \mathrm{~g}$ ) in planting holes during planting and or next to the seedlings after emergence $[8,9]$. The technique 
has been shown to improve crop productivity. For instance, a study in Benin found that micro dosing in maize increased productivity by $50 \%$ [21]; while yield increase of $68 \%$ was registered in finger millet and sorghum in sub Saharan Africa [25]. Recently in Uganda, $117 \%$ finger millet grain yield increase was observed at a combination of $\mathrm{N}$ and $\mathrm{P}$ fertilizer micro dose with weeding once at 20 days after sowing [7]. However, no conclusive study has been done to show the economic viability of fertilizer micro dosing technique especially in finger millet production in Uganda. More so the excessive labor used in managing weeds in finger millet production is well documented in Uganda but with no empirical evidence of how it affects profitability of the finger millet crop. This study therefore, was carried out to determine the profitability of fertilizer micro dosing and timing of weeding on finger millet production in eastern Uganda.

Profitability is the ability of a given investment to earn a return from its use $[3,16]$. A number of scholars use different methods in determining profitability of fertilizer application for example [14, 16, 23] used cost benefit analysis, where profitability of fertilizer applied was determined by obtaining a ratio of average maize $\mathrm{N}$ response which he called marginal physical product of nitrogen (MPP) and average physical product (APP) to give average value cost ratio (AVCR). A ratio of one means the farmer breaks even and greater than one means fertilizer application is profitable while less than 1 being non profitable [1]. Though this method was used to determine profitability of fertilizer application, non-fertilizer factors that influence crop performance are assumed to be held constant hence effective yield estimation may not be achieved thus affecting the average value cost ratio. Furthermore, [26] used the value cost ratio (VCR) in determining profitability of fertilizer application which is a ratio of the technical response to fertilizer use and the nutrient/output price ration. Similarly, this method of profitability analysis does not consider other factors that influence yield other than fertilizer. This makes it difficult to discern how fertilizer has influenced yield in simplicity. Partial budget techniques as adopted by [5] compare costs and benefits of alternatives faced by the farm business. It focuses on the changes in income and expenses in implementing a specific alternative and all farm incomes and expenses that are unchanged are ignored. Partial budgeting also allows consideration of other factors and practices that influence yield such as agronomic practices. In this study agronomic factors were not considered and therefore, this method could not be selected for profitability analysis. This method also required long duration studies for example studies that have lasted three and above years.

Gross margin analysis of profitability: The gross profit margin ratio, also known as gross margin, is the ratio of gross margin expressed as a percentage of sales were adopted for this study. Gross margin, alone, indicates how much profit a company makes after paying off its cost of goods sold. It is commonly used method in the determination of short duration project with less consideration on fixed cost in profitability analysis [10] which was the case in this study since majority of the farmers utilize the fixed costs (such as hand hoes and ox-ploughs) a cross several farm enterprises. Where, Gross Margin $=\sum$ (GFR-TVC) Where: GFR $=$ Gross field revenue and $\mathrm{TVC}=$ total variable costs [4]. The knowledge generated from this study will be important in facilitating further interventions in soil fertility and weed management as well as enable farmers to make informed decisions in adopting fertilizer micro-dosing technique as well as timely management of weeds to maximize productivity in finger millet crop production.

\section{Methodology}

\subsection{Study Area}

This study was conducted at Kuju Technology Verification Center (TVC) in Amuria District, in Eastern Uganda under rain fed condition [7]. The area receives mean annual rainfall of about $1200 \mathrm{~mm}$, distributed biannually (March - June and August - November). The soil is predominantly plinthosols with sandy loam textural classification.

\subsection{Experimental Procedure}

\subsubsection{Treatments}

The treatments included: micro dose application of $\mathrm{N}$ at 0 and $16.6 \mathrm{~kg} \mathrm{ha}^{-1}$ and full dose of $\mathrm{N}$ at $83 \mathrm{~kg} \mathrm{ha}^{-1}$; micro dose of $P$ at 0 and $10.6 \mathrm{~kg} \mathrm{ha}^{-1}$ and a full dose of $\mathrm{P}$ at $52 \mathrm{~kg} \mathrm{ha}^{-1}$ (Full dose of $\mathrm{N}$ and $\mathrm{P}$ as the control). Nitrogen was applied in the form of urea (46\%), in two splits of 50\% each; the first split applied at planting and second split at approximately 5\% flowering while Phosphorus was applied in the form of triple super phosphate (TSP), $\left(46 \% \mathrm{P}_{2} \mathrm{O}_{5}\right)$ at planting because it is sparingly soluble. The micro doses represented by one third of the full dose $\left(83 \mathrm{~kg} \mathrm{~N}\right.$ and $\left.52 \mathrm{~kg} \mathrm{P} \mathrm{ha}{ }^{-1}\right)$. After weighing the fertilizer equivalent to the experimental plot $(5 \mathrm{~m} \times 3 \mathrm{~m})$, the weighed fertilizer was divided by number of rows per plot to obtain the amount of fertilizer to be applied per row. In this case, each plot carried ten rows (each containing 30 plants), hence for the rate of $16.6 \mathrm{~kg} \mathrm{~N} \mathrm{ha}^{-1}$, each row in a plot was supplied with $2.1 \mathrm{~g}$ of urea, using a coca cola bottle top and the same procedure was followed for other fertilizer rates. After sowing finger millet seeds in furrows and burying them with a thin layer of top soil, nitrogen fertilizer was spot applied on top of the seeded furrows at $30 \mathrm{~cm}$ spacing between furrows. The applied fertilizer was also immediately covered with top soil. While for weeding regime treatments; double weeding at 20 and 45 DAS, single weeding at 20,30 and 45 DAS were imposed in the trial, since weeding has been one of the major bottlenecks in finger millet production in the study region.

\subsubsection{Design}

A randomized complete block design in split plot arrangement with three replications was used. Weeding regime treatments were the main plot; while fertilizer micro dosing treatments were the sub plots planted with SEREMI II finger millet variety in a plot size of $5 \mathrm{~m} \times 3 \mathrm{~m}$. Pests and 
disease control were not necessary since these were not prevalent during the study.

\subsection{Data Collection}

Data were collected on variable costs (seed, fertilizer, seed bed preparation, planting, weeding, harvesting, drying, threshing, bagging, transportation, and marketing during experimentation time) (Table 1). Also, grain yield per treatment in $\mathrm{kg} \mathrm{ha}^{-1}$ was recorded. Gross Field Revenue (GFR) was determined by obtaining the product of prevailing price of finger millet grain and the mean grain yield per hectare. The amounts of $\mathrm{N}$ and $\mathrm{P}$ fertilizers, and seeds used per plot were costed using the prevailing retail prices and later converted per hectare. Field operations, for example seed bed preparation, planting, fertilizer application, weeding, harvesting and threshing were also costed using prevailing labor cost in the study area (Table 1). Other offfarm variable costs such as produce transportation and marketing were considered. Finally, the Net Field Revenue (NFR) was determined by subtracting the Total Variable Costs (TVC) per hectare from the gross revenue per hectare as summarized in the equation below:

Gross field revenue $($ GFR $)=$ Yield of produce $\times$ its market price

Net Field Revenue (NFR) = Total Variable Costs (TVC) - Gross field revenue (GFR)

Table 1. Cost of inputs and Labor for one acre of finger millet.

\begin{tabular}{|c|c|c|c|c|c|}
\hline S/no. & Item Description & Unit & Unit cost (UGX) & Quantity & Total cost UGX \\
\hline 1 & Tripple super phosphate fertilizer & $50 \mathrm{~kg}$ bag & 130,000 & 1 & 130,000 \\
\hline 2 & Urea fertilizer & $50 \mathrm{~kg}$ bag & 130,000 & 1 & 130,000 \\
\hline 3 & Seed & Acre & 3000 & 4 & 12,000 \\
\hline 4 & Opening of land & Acre & 90,000 & 1 & 90,000 \\
\hline 5 & Second ploughing & Acre & 90,000 & 1 & 90,000 \\
\hline 6 & Discing & Acre & 70,000 & 1 & 70,000 \\
\hline 7 & Planting & Acre & 150,000 & 1 & 150,000 \\
\hline 9 & $2^{\text {nd }}$ weeding and $2^{\text {nd }}$ split of fertilizer application & Acre & 150,000 & 1 & 150,000 \\
\hline 10 & Harvesting & Man days & 5000 & 40 & 200,000 \\
\hline 11 & Threshing & Bags & 200 & 500 & 100,000 \\
\hline 12 & Transport & Lumpsum & - & - & 50,000 \\
\hline 13 & Bags & pcs & 1200 & 10 & 12,000 \\
\hline 14 & Drying and sorting and packaging & Lumpsum & - & - & 30,000 \\
\hline 15 & Total variable cost & & & & $2,714,000$ \\
\hline
\end{tabular}

Note: UGX= Uganda shillings, 3600 UGX=1 US \$

\subsection{Data Analysis}

In this study, profitability of each treatment was determined by gross margin analysis procedure as described by [5]. This method was selected because fixed costs were not considered due to the multiple use of farm assets a cross many enterprises/activities in a household. Also the period of experimentation was short (two seasons). Therefore, Gross Margin was calculated from: $\sum$ (GFR-TVC). Where: GFR= Gross field revenue and $\mathrm{TVC}=$ total variable costs

\section{Results}

\subsection{Cost Benefit Analysis of Fertilizer Micro Dosing}

\subsubsection{Cost Benefit Analysis of Fertilizer Micro Dosing in Finger Millet Production}

A combination of $\mathrm{N}$ and $\mathrm{P}$ micro dose $(16.6 \mathrm{~kg} \mathrm{~N} 10.6 \mathrm{~kg}$ $\mathrm{P}) \mathrm{ha}^{-1}$ recorded the highest gross margin of Uganda shillings (UGX) 2,956,180 and the lowest gross margin was observed at no fertilizer control treatment (UGX 683,430) (Table 2).

Table 2. Effect of $N$ and $P$ fertilizer micro dosing on profitability of finger millet production in eastern Uganda.

\begin{tabular}{llll}
\hline Fertilizer rates $\left(\mathrm{kg} \mathrm{ha}^{-1}\right)$ & TVC ha $^{-1} \mathbf{( U G X )}$ & GFR ha $^{-1}(\mathbf{U G X})$ & NFR ha $^{-1}\left(\mathbf{U G X}^{\mathbf{1}}\right)$ \\
\hline 16.6 N 10.6 P & $1,481,650$ & $4,437,830$ & $2,956,180$ \\
16.6 N & $1,320,200$ & $2,820,790$ & $1,500,590$ \\
10.6 P & $1,370,200$ & $3,388,340$ & $2,018,140$ \\
N0 P0 & $1,286,900$ & $1,970,330$ & 683,430 \\
N83 P53 & $1,881,650$ & $4,395,900$ & $2,514,250$ \\
\hline
\end{tabular}

Note: TVC $=$ Total variable costs; GFR= Gross Field Revenue; NFR= Net Field Revenue; UGX= Uganda shillings; 1 United States' dollar $(\$)=3600$ UGX.

\subsubsection{Influence of Nitrogen and Phosphorus Agronomic Use Efficiency in Fertilizer Micro-dosing Profitability} The effect of fertilizer micro dosing of $\mathrm{N}$ significantly $(\mathrm{P}<$
0.05) reduced $\mathrm{N}$ agronomic use efficiency; while micro dosing with sole $\mathrm{P}$ achieved a very high level of agronomic efficiency (Figure 1). On the other hand, combined micro dosing of $\mathrm{N}$ and $\mathrm{P}$ increased the agronomic efficiency of $\mathrm{N}$ 
(43.8 $\mathrm{kg} \mathrm{kg}^{-1}$ ), but reduced that of $\mathrm{P}\left(22.1 \mathrm{~kg} \mathrm{~kg}^{-1}\right)$. With regard to the full dose, combined application of $\mathrm{N}$ and $\mathrm{P}$ full dose performed quite poorly, with a low agronomic use efficiency value of $8.9 \mathrm{~kg} \mathrm{ka}^{-1}$ compared to the $\mathrm{N}$ and $\mathrm{P}$ micro dosing counterparts.

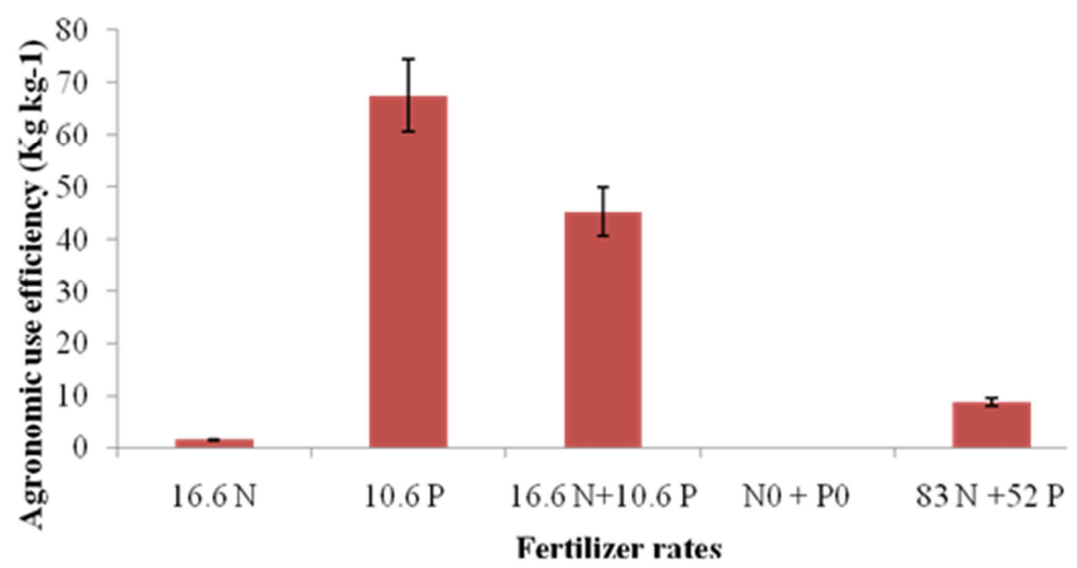

Figure 1. Effect of $N$ and $P$ single fertilizer micro-dosing and $N$ and $P$ fertilizer combinations on finger millet $N$ and $P$ use efficiency in eastern Uganda.

\subsection{Cost benefit Analysis of Different Weeding Regimes in Finger Millet Production}

Weeding once at 20 Days after Sowing (DAS) had a positive percentage MRR (116.8). The rest of the weeding regimes (weeding at $20 \& 45$ DAS, 30 DAS and 45 DAS) were dominated and therefore were not considered for cost benefit analysis (Figure 2). This therefore means that it is not cost effective to weed finger millet at 20 \& 45 DAS, 30 DAS and 45 DAS.

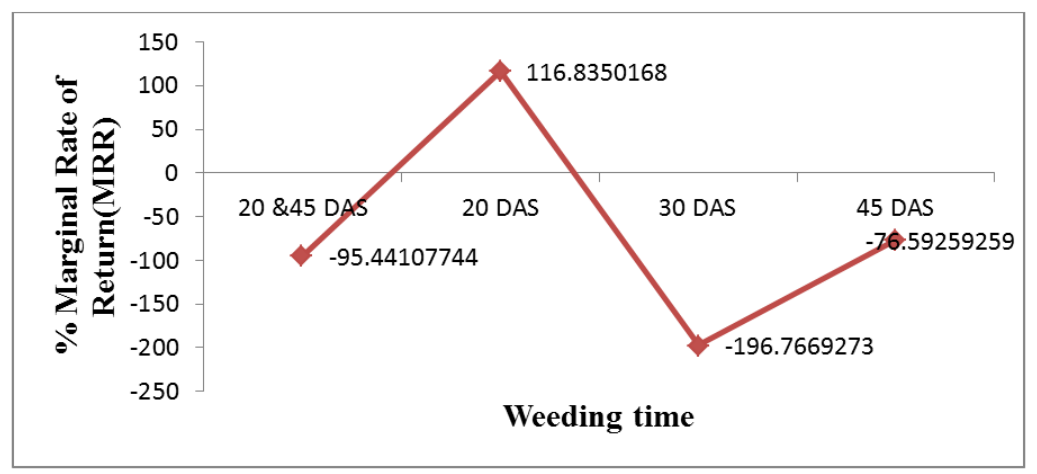

Suffix: DAS= Days after Sowing

Figure 2. Cost benefit analysis of four weeding regimes in finger miller production.

\subsection{Effect of Interaction of Time of Weeding with Fertilizer Micro Dosing on the Profitability of Finger Millet}

The interaction of weeding time (20 DAS) and a combination of $\mathrm{N}$ and $\mathrm{P}$ fertilizer micro dosing $(16.6 \mathrm{~kg} \mathrm{~N}$ ha${ }^{1}$ and $\left.10.6 \mathrm{~kg} \mathrm{P} \mathrm{ha}^{-1}\right)$, recorded the highest gross margin of UGX 1,984,220 (\$ 551), (Table 3.) This was followed by interaction between weeding time (20 DAS) and sole application of $\mathrm{N}$ micro dose $\left(16.6 \mathrm{~kg} \mathrm{~N} \mathrm{ha}^{-1}\right)$ with net field revenue of UGX 1,812,720 (\$504). An interaction of $\mathrm{N}$ and $\mathrm{P}$ fertilizer micro dose with weeding at 30 DAS registered the third highest Net Field Revenue (NFR) of UGX 1,528,400 (\$ 424). No fertilizer control (P at $0 \& \mathrm{~N} 0 \mathrm{~kg} \mathrm{ha}^{-1}$ ) recorded the lowest gross margin of UGX 373,000 (\$103).

Table 3. Effect of $N$ and P fertilizer micro dosing and time of weeding on profitability of finger millet production in eastern Uganda.

\begin{tabular}{|c|c|c|c|c|c|}
\hline \multirow{2}{*}{$\begin{array}{l}\text { Weeding time } \\
\text { X Micro-dosing rates }\end{array}$} & 20 DAS & 30 DAS & $20 \& 45$ DAS & 45 DAS & \multirow{2}{*}{ Total NFR } \\
\hline & \multicolumn{4}{|c|}{ Profitability (UGX) } & \\
\hline$(16.6 \mathrm{~N} \& 10.6 \mathrm{P}) \mathrm{kg} \mathrm{ha}^{-1}$ & $1,984,220$ & $1,528,400$ & $1,117,850$ & 982,660 & $5,613,130$ \\
\hline$(16.6 \mathrm{~N}) \mathrm{kg} \mathrm{ha}^{-1}$ & $1,812,720$ & $1,437,320$ & 833,340 & 889,490 & $4,972,870$ \\
\hline$(10.6 \mathrm{P}) \mathrm{kg} \mathrm{ha}^{-1}$ & $1,286,340$ & 610,100 & $1,763,840$ & 459,260 & $4,119,540$ \\
\hline$(0 \mathrm{P} \& 0 \mathrm{~N}) \mathrm{kg} \mathrm{ha}^{-1}$ & 373,000 & $1,168,390$ & $1,462,700$ & $1,052,400$ & $4,056,490$ \\
\hline $7(83 \mathrm{P} \& 52 \mathrm{~N}) \mathrm{kg} \mathrm{ha}^{-1}$ & $1,105,550$ & 970,360 & 626,100 & $1,087,140$ & $3,789,150$ \\
\hline
\end{tabular}

Note: UGX= Uganda shillings; $1 \$=3600$ UGX; NFR= Net Field Revenue. 


\section{Discussion}

The existence of interaction of fertilizer micro dosing of $\mathrm{N}$ and $\mathrm{P}$ on the profitability of finger millet (Table 2) is evidence of the synergetic role of $\mathrm{N}$ and $\mathrm{P}$ in finger millet nutrition. Isolation of $\mathrm{N}$ or $\mathrm{P}$ alone is insufficient to achieve desired grain yield and consequently profitability in finger millet production. Even more so, the superiority of $\mathrm{P}$ in agronomic efficiency, which was noted to be the most limited compared to $\mathrm{N}$ [13], is also not enough to give conclusive results without considering the critical weeding time for finger millet which if not timed well would affect grain yield and consequently profitability. The superior performance of the combination of $\mathrm{N}$ and $\mathrm{P}$ fertilizer micro dosing over the full dose $(83 \mathrm{~kg} \mathrm{~N}$ and $52 \mathrm{~kg} \mathrm{P})$ per hectare further over scores the observations made in this study (Table 2), where micro dosing recorded the highest net field revenue (UGX $2,956,180)$ and agronomic efficiency of $53 \mathrm{~kg} \mathrm{~kg}^{-1}$ than full dose. Studies conducted by [15] on rice noted that economic efficiency lies between a point of maximum $\mathrm{AE}$ and maximum yield. Therefore, the coincidence of AE efficiency and economic efficiency in the present study suggests that we were operating at the maximum agronomic efficiency.

The observed positive Marginal Rate of Return (MRR) under weeding at 20 DAS (Figure 2) and the negative MRR when weeding was done at 30 and 45 Days after Sowing (DAS) suggests that finger millet needs to be weed free at a particular period in its growth (critical weed competition period) which lies between 20-30 DAS. It therefore, reflects and confirms the findings of [2] who observed that finger millet yield increased when weeding was done between 2030 DAS after sowing. Furthermore, finger millet requires adequate nutrients at the early stages of growth and if the nutrient availability to the crop is affected as a result of weed competition due to delayed weeding, finger millet performance will be hindered. This is in agreement with the finding of $[11,17]$. They both observed that nutrients especially NPK are required at the early stage of finger millet growth. It is important to note that weeding at 20 DAS was generally superior to all treatment combinations; including double weeding $(20$ \& 45 DAS $)$ which has been recommended by several researchers in the region [20, 24]. It is also worth-while noting that, the timing and number of weeding sessions may change depending on the nature and extent of seed-bed preparation prior to planting [12]. In this study, the field was under legume cereal rotation which consequently reduced weed biomass. Therefore, the initial weed population and biomass was less than would be the case of a virgin land. Also seed bed preparation involved first and second ox-Ploughing into a fine seed-bed. Hence, the conclusion from the economic assessment of weeding time based on this study must be contextualized with differences in seed-bed preparation before finger millet is sown. It further suggests that there is a close relationship between weed management and nutrient utilization and agronomic efficiency by the finger millet crop.
The high gross margin (UGX 1,984,220) on application of $\mathrm{N}$ at $16.6 \mathrm{~kg} \mathrm{ha}^{-1}$ and $\mathrm{P}$ at $10.6 \mathrm{~kg} \mathrm{ha}^{-1}$ combined with weeding at $20 \mathrm{DAS}$ is empirical evidence of the synergetic role played by $\mathrm{N}$ and $\mathrm{P}$ in the growth and development of the plant. This synergy is further enhanced with timing of weeding which happened to be at 20 DAS. Weeding once at 20 DAS and N and $\mathrm{P}$ fertilizer micro dose application is therefore, the most profitable combination in eastern Uganda and could make farmers earn profit of Uganda shillings 1,984,220 per hectare, compared to only Uganda shillings 373,000 on none application of fertilizer and; only Uganda shillings 1,105,550 on application of full dose of fertilizer per hectare.

\section{Conclusion}

a) Finger millet production was profitable when weeding was done once at 20 days after sowing.

b) The highest profit of 1,984,220 Uganda shillings (\$ 551) was obtained from application of $\mathrm{N}$ and $\mathrm{P}$ (16.6 $\mathrm{kg} \mathrm{N} \mathrm{ha}{ }^{-1}$ and $10.6 \mathrm{~kg} \mathrm{P} \mathrm{ha}^{-1}$ ) fertilizer micro dosing with weeding at 20 DAS.

c) Nitrogen agronomic efficiency is enhanced by $P$ fertilizer application in fertilizer micro dosing.

\section{Recommendation}

Fertilizer micro dosing of $\mathrm{N}$ and $\mathrm{P}\left(16.6 \mathrm{~kg} \mathrm{~N} \mathrm{ha}^{-1}\right.$ and 10.6 $\mathrm{kg} \mathrm{P} \mathrm{ha}{ }^{-1}$ ) and weeding at 20 DAS should be adopted and scaled out for use by finger millet producers in eastern Uganda to be able to make maximum economic and environmental gains

Nitrogen fertilizer should be applied together with $\mathrm{P}$ fertilizer in fertilizer micro dosing in order to obtain maximum benefit from their synergetic role in yield enhancement and consequently profitability.

\section{Acknowledgements}

Appreciation is extended to Harnessing Opportunities for Productivity Enhancement of Sorghum and Millets II (HOPE II) and $\mathrm{M}^{\mathrm{c}} \mathrm{KNIGHT}$ Foundation for funding this research.

\section{References}

[1] Abdalla, E. A., Osman, A. K., Maki, M. A., Nur, F. M., Ali, S. B., \& Aune, J. B. (2015). The Response of Sorghum, Groundnut, Sesame, and Cowpea to Seed Priming and Fertilizer Micro-Dosing in South Kordofan State, Sudan. Agronomy, 5 (4), 476-490. https://doaj.org

[2] Asargew, F., \& Shibabawu, A. (2014). Appropriate Time for Weed Management for Finger millet (Eleusin coracana Goartn). Journal of Natural Sciences Research, Vol. 4 (16).

[3] Asika, E. R., Chitom, J.-A. R., \& Chelichi, I. F. (2017). Appraisal of Human Resource Accounting on Profitability of Corporate Organization. Economics, 6 (1), 1. https://doi.org/10.11648/j.eco.20170601.11 
[4] Bhimani, A., Horngren, C. T., Datar, S. M., \& Foster, G. (2008). Management and cost accounting. FinancialTimes Prentice Hall. http://www.dawsonera.com/guard/protected/dawson.jspdawso nera.com/depp/reader/protected/external/AbstractView/S9781 408212127

[5] CIMMYT Economics Program (Ed.). (1988). From agronomic data to farmer recommendations: An economics training manual (Completely rev. ed). CIMMYT Economics Program.

[6] Cobo, J. G., Dercon, G., \& Cadisch, G. (2010). Nutrient balances in African land use systems across different spatial scales: A review of approaches, challenges and progress. Agriculture, Ecosystems \& Environment, 136, 1-15. https://doi.org/10.1016/j.agee.2009.11.006

[7] Ekwangu, J., Anguria, P., Andiku, C., Tenywa, J. S., Bisikwa, J., Wanyera, N., \& Ugen, M. A. (2020). Fertilizer Microdosing and Timing of Weeding for Enhancing Finger-Millet Production in Eastern Uganda. Journal of Agricultural Science, $12 \quad$ (11), 290. https://doi.org/10.5539/jas.v12n11p290

[8] ICRISAT. (2006). Fertilizer micro dosing for the prosperity of small-scale farmers in the Sahel (Global Theme on Agro Ecosystem Report No. 23) [Annual report]. ICRISAT.

[9] ICRISAT. (2013). Annual report 2013. Issuu. https://issuu.com/icrisat/docs/annual_report_2013

[10] Jagelavicius, G. (2013). Gross margin management framework for merchandising decisions in companies with large assortment of products. Economics and management, 18 (1), 6-16-16. https://doi.org/10.5755/j01.em.18.1.4116

[11] Kamara, A. Y., Ewansiha, S. U., \& Menkir, A. (2014). Assessment of nitrogen uptake and utilization in drought tolerant and Striga resistant tropical maize varieties. Archives of Agronomy and Soil Science, 60 (2), 195-207. https://doi.org/10.1080/03650340.2013.783204

[12] Knight, A. M., Everman, W. J., Jordan, D. L., Heiniger, R. W., \& Smyth, T. J. (2017). Interactions of Nitrogen Source and Rate and Weed Removal Timing Relative to Nitrogen Content in Corn and Weeds and Corn Grain Yield. International Scholarly Research Notices, 2017.

[13] Kyomuhendo, P., Tenywa, M. M., Semalulu, O., Lenssen, A. W., Yost, R. S., Mazur, R. E., Kyebogola, S., \& Goettsch, L. H. (2018). Limiting nutrients for bean production on contrasting soil types of Lake Victoria Crescent of Uganda. African Crop Science Journal, 26 (4), 543-554-554. https://www.ajol.info/index.php/acsj/article/view/180284

[14] Mather, D., Waized, B., Ndyetabula, D., Temu, A., \& Minde, I. (2016). The profitability of inorganic fertilizer use in smallholder maize production in Tanzania: Implications for alternative strategies to improve Smallholder maize productivity. 45.

[15] Nair, S., Johnson, J., \& Wang, C. (2013). Efficiency of Irrigation Water Use: A Review from the Perspectives of
Multiple Disciplines. Agronomy Journal, 105, 351-363. https://doi.org/10.2134/agronj2012.0421

[16] Nestor, A., Clementina Uchenna, A., \& Juliet, O. (2017). Effect of human resource accounting on profitability of selected quoted telecommunication firms in Nigeria. Contemporary Issues in Business Management.

[17] Opole, R. A., Prasad, P. V. V., \& Staggenborg, S. A. (2013). Effect of seeding and nitrogen fertilizer application rates on field performance of finger millet. 11th African Crop Science Proceedings, Sowing Innovations for ustainable Food and Nutrition Security in Africa. Entebbe, Uganda, 14-17 October, 2013, $127-135$. https://www.cabdirect.org/cabdirect/abstract/20163288716

[18] Owere, L., Tongoona, P., Derera, J., \& Wanyera, N. (2014). Farmers' Perceptions of Finger Millet Production Constraints, Varietal Preferences and Their Implications to Finger Millet Breeding in Uganda. Journal of Agricultural Science, 6 (12). https://doi.org/10.5539/jas.v6n12p126

[19] Statistical Abstract UBOS 2012. Retrieved November 29, 2018, from http://www.ubos.org/onlinefiles/uploads/ubos/pdf\%20docume nts/2012StatisticalAbstract.pdf

[20] Tenywa, J. S., Nyende, P., Kidoido, M., Kasenge, V., Oriokot, J., \& Mbowa, S. (1999). Prospects and constraints of finger millet production in Eastern Uganda. African Crop Science Journal, Vol. 7. No. 4, Pp. 569-583, 1999. https://space.library.utoronto.ca/html/1807/20155/cs99048.ht $\mathrm{ml}$

[21] Tovihoudji, P., Akponikpe, I., Agbossou, E., Bertin, P., \& Bielders, C. (2017). Fertilizer microdosing enhances maize yields but may exacerbate nutrient mining in maize cropping systems in northern Benin. Field Crops Research, 213, 130 142. https://doi.org/10.1016/j.fcr.2017.08.003

[22] UBOS. (2019). UBOS statistical abstract [Survey report].

[23] Velde, M. van der, See, L., You, L., Balkovič, J., Fritz, S., Khabarov, N., Obersteiner, M., \& Wood, S. (2013). Affordable Nutrient Solutions for Improved Food Security as Evidenced by Crop Trials. PLOS ONE, 8 (4), e60075. https://doi.org/10.1371/journal.pone.0060075

[24] Wanyera, N. M. W. (2007). Finger-millet (Eleusine coracana (L) Gaertn) in Uganda. Proceedings of the First International Finger Millet Stake-Holders Workshop, Projects R8030 \& 8445, UK Department for International Development - Crop Protection Programme Held on 13th - 14th September 2005.

[25] Yacouba, O., Taonda, J.-B., Serme, I., Tychon, B., \& Bielders, C. (2020). Factors driving cereal response to fertilizer microdosing in sub-Saharan Africa: A meta-analysis. Agronomy Journal, 112. https://doi.org/10.1002/agj2.20229

[26] Yanggen, D., Kelly, V., Reardon, T., \& Naseem, A. (1998). Incentives for Fertilizer Use in Sub-Saharan Africa: A Review of Empirical Evidence on Fertilizer Response and Profitability. 129. 